\title{
Finaneial Mrarket
}

\section{Central European Review of Economics \& Finance}

Vol. 25, No. 3 (2018), pp. 67-82

DOI: $10.24136 /$ ceref.2018.016

Received: 16 January 2018. Accepted: 2 May 2018

\author{
Grażyna A. OLSZEWSKA ${ }^{1}$
}

\section{FOREIGN CURRENCY LOANS AND STABILITY OF THE BANKING SYSTEM IN POLAND}

\begin{abstract}
The aim of the study was to answer the question whether and to what extent foreign currency loans may pose a threat to the stability of the banking system in Poland. The reason for exploring this problem is the situation in which Swiss franc mortgage loan parties found themselves. The problem concerned not only Poland, but also appeared in Hungary, Spain and Ukraine. The aforementioned countries have adopted various strategies in order to solve this issue. Currently, there is a discussion in Poland over the form of solution to the situation in which the Swiss franc debtors have found themselves. This article presents the following hypotheses:

- The credit policy of banks, which includes mortgage lending in Swiss francs, was a typical action in terms of risk management which in this case was two-way in nature. In addition, banks did not have the opportunity to significantly impose its policies on customers, as evidenced by the degree of market development and market competition.

- Conversion of mortgage loans according to the CHF historic exchange rate can affect the stability of the banking system.

The article presents the main types and sources of bank risks with particular emphasis on credit risk and foreign exchange risk. In addition, the paper shows the importance of this kind of risk in the context of the systemic stability of the banking sector in a situation of exchange rate stability disturbances. Verification of the research hypothesis was based on literature studies and analysis of statistical data.
\end{abstract}

Keywords: Banking system, bank risk, foreign exchange risk.

JEL Classification Codes: E58, E44, G21.

\footnotetext{
${ }^{1}$ Assistant Professor, Ph.D., University of Technology and Humanities in Radom, Faculty of Economics and Legal Sciences.
} 


\section{Introduction}

Allocation of resources is the main task of banks in any market economy. It is often wrongly limited to accepting deposits and giving loans. However, to make it fully and effectively implemented, banks also have make payments and enable the same to other market participants, transform amounts and dates of money flows, collect and process information and provide other market participants with it, take the risk over from other market participants and create instruments serving the purpose of market management and offer them to market participants. Risk is a common phenomenon in bank activities. It is of a complex and multi-dimensional nature. Majority of risk factors derive from information asymmetry. This phenomenon consists in the fact that the scope of information which is in the possession of the parties entering into transaction is varied (Pietrzak, Polański, Woźniak, 2008, p. 21).

The banks which are involved in transactions establish with other market participants relationships at the macro-, mezzo- and microeconomic levels. At the macroeconomic level it is expected from banks to display behaviours of positive impact on economic growth and strengthening national economy. At the mezzoeconomic level banks should pursue their objectives giving due consideration to maintaining balance and long-term benefits for the region and entities within the area of their activities. Direct relationships with clients form for a bank a plane to meet microeconomic objectives. At this level the bank should aim at gaining profits while simultaneously observing the safety principle.

Ignoring the safety principle may lead to a loss of social confidence in a single bank and, consequently, the occurrence of the domino effect. Due to the significance of this phenomenon, every financial system has financial supervision guarding the safety of banks and other institutions belonging to the system.

Maintaining the safety of bank activities is in the best interest of all markets participants. However, bank clients, in particular depositaries but also borrowers, are very sensitive to the issue of safety because financially weak banks are not able to raise funds which would satisfy demand for loans. It can be said that the proper assessment of risk factors in the financial market determines evaluation of loan funds which are to be the subject of a transaction within the framework of bank activities at the microeconomic level. It determines the costs to be incurred by borrowers, interest rates on depositaries' deposits and profits which will be earned by a bank.

On account of the scale of their activities, banks have an advantage over individual clients in the field of gaining information indispensable for risk assessment as well as its diversification. However, they are not able to affect or fully control its development.

The aim of the study was to answer the question whether and to what extent foreign currency loans may pose a threat to the stability of the banking system in Poland. The reason for exploring this problem is the situation in which Swiss franc mortgage loan parties found themselves. The problem concerns not only Poland, but it also appeared 
in Hungary, Spain and Ukraine. The aforementioned countries have adopted various strategies in order to solve this issue. Currently, there is a discussion in Poland over the form of solution to the situation in which the Swiss franc debtors have found themselves.

This article presents the following hypotheses:

- The credit policy of banks, which includes mortgage lending in Swiss francs, was a typical action in terms of risk management which in this case was two-way in nature. In addition, banks did not have the opportunity to significantly impose its policies on customers, as evidenced by the degree of market development and market competition.

- Conversion of mortgage loans according to the CHF historic exchange rate can affect the stability of the banking system.

The article presents the main types and sources of bank risks with particular emphasis on credit risk and foreign exchange risk. In addition, the paper shows the importance of this kind of risk in the context of the systemic stability of the banking sector in a situation of exchange rate stability disturbances. Verification of the research hypothesis was based on literature studies and analysis of statistical data.

\section{Stability of the banking system and its significance for economic growth}

In source literature the concept of the banking system appears very often, however, the way in which it is defined by particular authors concentrates around the same elements. The differences result from a different approach to the term defined.

In the institutional approach, the banking system can be defined as a collection of institutions which - depending on the adopted model - consists of different types of banks functioning in particular segments of the financial market (Pietrzak, Polański, 1997, p. 39). Alternatively, it can be said that the banking system is an organised set of elements being banks and relationships among them (Milczewska, 1997, p. 7).

Still another way of approaching the problem of defining the place of the banking system in financial markets and the role of banks as financial intermediaries is the functional approach. This approach is represented by a view that development of the banking systems is passive or, in other words, it is an after-effect of the market economy development (Jaworski, 1998, p. 16). In this approach the definition of the banking system comes down to the definition of its role in economy of a given country. The banking system activity focuses on allocation of resources gained from their depositaries into different kinds of investment in order to multiply them or keep their value (Kaszubski, 2006, p. 56). In accordance with this approach the banking system is a network of banking institutions inter-connected by money markets. In this approach the place and role of the banking system in the financial market structure of a given country depends on the size of money aggregates (Jaworski, 1998, pp. 17-20). Thus, the banking system is a logical and coherent whole created from financial - banking and non-banking - institutions of a given country together with the legal regulations in force. 
In the functional approach a very important element is referring by the authors of the definitions to the traditional role of the bank as an intermediary in transformation of savings of some economic entities into investment capital of others. And this financial intermediation between end-creditors and end-borrowers determines the unique role of banks in the market (Merton, 1995, pp. 23-24). An element which distinguishes banks from other financial institutions, such as, insurance societies, pension funds or investment funds, is the fact that banks are the only institutions which create money and organise circulation of money through implementation of inter-bank settlements. This explains their special role in the monetary impulse transmission to economy.

Depending on what in a given market is treated as money, considering all the functions fulfilled by it, it will decide about the number and type of these institutions. Such a way of perceiving the banking system is of dynamic character because it is based on analysis of continuous transformations of elements making up the banking system (Olszewska, 2013, p. 51).

The banking system products are monetary impulses and money flows carried out among different types of economic - financial and non-financial - entities. While analysing the place and role of banks in the financial system one must emphasise the fact that these are banks which in the system fulfil the roles, which non-banking financial institutions are not able to fulfil. These functions include:

- taking the risk over by giving bank guarantees,

- creating and servicing the system of money settlements between business entities,

- and the most important element distinguishing banks:

possibility of money creation through accepting deposits and giving loans.

It is owing to the possibility of money creation which determines the volumes of money supply that banks are price-setting institutions in the money market. Additionally, due to its availability to an average customer, regardless of the fact whether it is a natural person or an economic entity, the "banking channels" of the monetary policy impulse flows to economy have the broadest reach. Therefore, the stability of the banking system is often identified with financial stability. The latter, in turn, constitutes a fundamental condition of every country's economy functioning. It forms a basis of rational decisions about capital allocation supporting effective operating of economic entities (Skrzypek, 2007).

One of the ways of defining financial stability is a negation-based statement, namely that financial stability must be understood as lack of the financial crisis threat, but also a situation in which there is no systemic risk (Lastra, 2006, p. 13). A systemic risk, means, in turn, a situation in which the crisis occurring in one country or region becomes a direct cause of the financial system instability in another country or region. In view of financial market globalisation the crisis often has an international dimension. It happened so on many occasions in the history of the financial market development. An example here can be the crisis in 2007. Turbulences in functioning of financial institutions important for the system is also an example of the systemic risk occurrence which 
can be accompanied by reduced or no confidence of the financial market participants in its particular institutions. In practice this can mean disintegration of the financial system as a result of a domino effect, external shock or loss of security of economic turnover due to a terrorist attack or organised crime (Solarz, 2008, p. 19).

In a positive approach generally the term "financial stability" defines a situation in which the financial system functions properly, i.e. its functioning is not disturbed in any way. The most important aspects of modern economy include: risk identification and assessment, creating conditions for effective management of the diagnosed risk and effective allocation of financial resources. All these elements lead to financial security (Ksiazzepolski, 2004, p. 160). However, the very creating of these conditions does not guarantee that particular market participants achieve expected results of undertaken activities. Thus, financial stability is not synonymous with effectiveness.

Financial crises which have occurred since the 1950s prove that the banking sector, which is a foundation of every country's financial market, is of key importance for financial stability. These are banks which can create money and these are irregularities in their functioning (especially those connected with credit policy) which happen to be the main cause of financial crises, determine their course and social and economic costs. As it is state budget which covers a major part of the financial crisis costs, the state must have at its disposal "the tools" for systemic risk monitoring, valuation and management in the form of the so called financial security network. At the national level, this network consists of the financial market supervision (frequently of integrated nature), the last-instance lender (it is the central bank on which this function is imposed directly by legal regulations) and the deposit insurance system. An obvious consequence of internationalisation of national financial systems is connection of national security networks with one another at the regional or international levels. Despite differences in the division of preventive functions, crisis management functions and management function among particular elements of national security networks, they can create "early warning systems" at the transnational level (Szczepańska, Sotomska-Krzysztofik, Pawliszyn, Pawlikowski, 2004, pp. 6-7). It is particularly important in the situation of the increasing supremacy of the financial system or kind of its breakaway from the real sector of economy. In some circumstances it may mean negative correlation along the line "financial development - economic development" (Krahnen, Schmidt 1994, pp. 9-10). It is possible in the situation when savings of economic entities instead of being a source of financing investment are intended to be used by banks or financial institutions for other purposes, like e.g. speculative operations on an international scale or a necessity to cover costs of non-standard risk. Many economic crises originated in speculative attacks on currencies of less developed countries. Interventions in the foreign exchange markets mean a loss of reserves and a possibility of refinancing weaker banks. This may result in the financial market destabilisation and necessity of state funding for particular institutions. An additional factor having an adverse effect on economic growth is absorption by 
the financial system of savings which otherwise could be transformed into investment but serve the purpose of maintaining frequently ineffective infrastructure of the system (Żyrzyński, 2006, p. 546). In the last decades solutions of different types dealing with restructuring processes of banks' credit portfolios, or even the entire banking systems, abounded (Majewska, 2001). Therefore, the projects presented by the Polish government aiming at helping these bank clients who took loans in Swiss francs seem to be irrational from the point of view of the role of state in maintaining financial stability.

\section{Bank risk in the current situation in foreign exchange markets}

In bank activities risk has always been present, however, together with the development of the banking sector and its environment, the sources and scale of risk to which they were exposed have changed.

Source literature presents several definitions of risk. The main difference is in the very understanding of variability of results. Some authors treat risk as a possibility of changes in a result in relation to the one assumed in the decision-making process. It is a positive risk, which can also be defined as speculative (Gąarek, Maksymiuk, Krysiak, Witkowski, 2001, p. 7). This type of approach to risk is usually applied in financial risk management. Financial risk is connected with the capital structure of the economic entity's balance sheet and it refers to both financial and non-financial entities (Janasz, 2013, p. 174). Among financial entities, financial market institutions are most exposed to this kind of risk (Williams, Smith, Young, 2012, pp. 41-43). We speak about negative risk when a change in a result is one-sided, which means only a possibility of its deterioration. This type of risk is also defined as "pure". In financial markets this type of risk refers mainly to banks and is connected with credit giving activities (PrzybylskaKapuścińska, 2001, pp. 31-33).

Bank risk results from performing different banking operations. Therefore, it cannot be restricted to credit giving activity reserved for banks only. We cannot treat it as a danger leading to deterioration of the financial result and occurrence of other irregularities which may result, for example, in bankruptcy (Rajczyk, 1997, p. 50). In banking practice there are quite a number of situations which may lead to both profits and losses. Uncertainty about the course of events related to banking activities is a complex problem and it requires a continuous and careful management process (Fedorowicz, 1996, pp. 6-7).

The authors of the bank risk definitions presented in source literature have not reached agreement on the issue whether in banking activities we deal with risk or uncertainty. One of the approaches assumes that risk appears when it is possible to determine a quantitative result of the decisions made (Jajuga, 1996, p. 99 and Stoner, Wankler, 1996, pp. 125-126). However, in the situation where a probability distribution of a specific result occurrence is not known we deal with uncertainty (Knight, 1971, p. 13). A complex nature of the bank risk and the fact that many of its components 
cannot be measured means that we can assume that banking activities (or broadly speaking, financial activities) are burdened not so much with risk but rather uncertainty.

For the purposes of this paper it was assumed that in their activities banks deal with risk whose multi-factor nature makes it impossible to measure it in its entirety. The factors of bank risk have a double nature. Firstly, they are technical and operational risks; secondly - a set of financial risks. Technical and operational risks result from work organisation, staff competencies or efficiency of IT systems. On the other hand, financial risk consists of: liquidity risk, interest rate risk, credit risk, exchange rate risk, operational risk, transactional risk and strategic and systemic market risks. The latter type of risk can derive from different - above mentioned - causes but it is the scale of effects, sometimes dramatic for market participants, that allows us to define them as systemic ones (Kaufman, 1996, p. 23). On many occasions these were market participants who through wrong risk assessment underlying their decision making provoked other entities to undertake specific activities and these, in turn, led to a loss of balance in the market and a change in the value of assets quoted on the market (Danielsson, Zigrand, Shin, 2009, p. 6).

In open economy, majority of financial institutions are international in nature. They conduct their business activities in several or more countries at the same time. Consequently, they are simultaneously exposed to the above mentioned risk factors rooted in different markets and assuming different values. In the situation of disturbed macroeconomic balance and recession resulting from the 2008 financial crisis, it was the foreign exchange risk that turned out to be particularly painful for market participants.

The foreign exchange risk means a possibility of suffering financial losses as a result of foreign exchange fluctuations. In the floating foreign exchange system this risk must be incessantly managed which is not synonymous with risk avoidance. Full foreign exchange risk management consists in using all information and abilities to evaluate it and ensure the expected yield in relation to the size of risk.

In the case of foreign exchange risk limited predictability concerns the value of foreign exchange rates in the future, however, potential losses may appear in the future in two areas:

- exchange rate losses noted,

- lost profits.

In the latter case the loss of profits from exchange rate gains can result from the entity's use of inappropriate in a given market situation, hedging instruments or other factors. It can be, for example, an administrative decision forcing an entity, in this case a bank, to recalculate its currency positions using the exchange rate different from the market one. If we assume that it refers only to the money due to a bank, it can mean not only lost profits but even a loss. Such a solution can be a real threat to the banking system stability. The ability to absorb losses incurred by a single bank, including its bankruptcy, may turn out problematic (Olszewska, 2015, p. 125). When this concerns 
many banks it can be impossible to carry out, especially in the situation of the freedom of deposit outflows from national banks to foreign markets. At present, in open economy, it is possible for the EU citizens without increased transfer costs. The outflow of savings can occur as a result of depositaries' reduced confidence in national banking institutions or in order to avoid costs passed on by banks to customers. The second variant is very probable. It is indicated by the solutions adopted in the field of financial supervision in the EU market (Olszewska 2012, pp. 228-229). Increased prudential regulations and costs related to them are passed on to other institutions creating the system and gradually they assume a transnational character.

\section{Significance of the exchange rate risk for banks in Poland, as exemplified by CHF loans}

In the Polish financial market the exchange rate risk plays a significant role. The Polish zloty is not a hard currency free of fluctuations. Despite the fact that after the 2008 financial crisis the GDP growth rate was positive, the zloty exchange rate against key currencies (USD, EURO, GBP or CHF) was strongly depreciated. Most probably speculations in the currency markets were responsible for that. The forecasts based on economic and political factors pointed to stability or even appreciation of the zloty exchange rate. Table 1 presents development of average exchange rates as of the last day of month.

In the analysed period CHF was the strongest in relation to the zloty. It was justified by political decisions of the Swiss government and the monetary policy strategy of the Swiss central bank. It was quite a surprise to market participants and resulted in changes in demand for financial instruments, especially loans, denominated in foreign currencies. The demand from households for loans denominated in the Polish zloty and in foreign currencies is presented in table 2.

Analysis of the data outlined in tables 1 and 2 shows that households reacted to changes in exchange rates with some delay. This can be accounted for by confidence in domestic currency and conviction about a temporary depreciation of the zloty. An additional factor was the interest rate which was twice lower in the case of loans denominated in zloty than in the case of foreign currency loans.

For the borrowers who were indebted in foreign currencies the depreciation of the zloty means higher costs of debt servicing. The borrowers who took loans in CHF felt them particularly severely. The data concerning changes in the value of $\mathrm{CHF}$ loans in relation to wage growth in the enterprise sector and general indebtedness are presented in table 3 . On the basis of the data it can be concluded that the situation of borrowers having loans in CHF deteriorated because of higher instalment values expressed in PLN, however, their wages also rose in the same period. Our data cover the period from the beginning of 2005 till the end of 2010 . 
Table 1. Table of the NBP (National Bank of Poland) exchange rates, month end average, for USD, EURO, CHF, GBP in the period 2007-2015

\begin{tabular}{|c|c|c|c|c|c|c|c|c|c|}
\hline & USD & EURO & CHF & GBP & & USD & EURO & CHF & GBP \\
\hline 12-2007 & 2.4350 & 3.5820 & 2.1614 & 4.8688 & $11-2011$ & 3.4248 & 4.5494 & 3.7112 & 5.3234 \\
\hline $1-2008$ & 2.4438 & 3.6260 & 2.2562 & 4.8593 & 12-2011 & 3.4174 & 4.4168 & 3.6333 & 5.2691 \\
\hline $2-2008$ & 2.3155 & 3.5204 & 2.2083 & 4.5901 & $1-2012$ & 3.2032 & 4.2270 & 3.5054 & 5.0496 \\
\hline $3-2008$ & 2.2305 & 3.5258 & 2.2446 & 4.4266 & $2-2012$ & 3.0730 & 4.1365 & 3.4318 & 4.8973 \\
\hline 4-2008 & 2.2267 & 3.4604 & 2.1437 & 4.3822 & 3-2012 & 3.1191 & 4.1616 & 3.4540 & 4.9908 \\
\hline $5-2008$ & 2.1824 & 3.3788 & 2.0767 & 4.3004 & 4-2012 & 3.1509 & 4.1721 & 3.4731 & 5.1295 \\
\hline $6-2008$ & 2.1194 & 3.3542 & 2.0907 & 4.2271 & 5-2012 & 3.5372 & 4.3889 & 3.6545 & 5.4858 \\
\hline $7-2008$ & 2.0509 & 3.2026 & 1.9596 & 4.0637 & 6-2012 & 3.3885 & 4.2613 & 3.5477 & 5.2896 \\
\hline $8-2008$ & 2.2691 & 3.3460 & 2.0723 & 4.1581 & $7-2012$ & 3.3508 & 4.1086 & 3.4206 & 5.2567 \\
\hline $9-2008$ & 2.3708 & 3.4083 & 2.1587 & 4.2885 & 8-2012 & 3.3353 & 4.1838 & 3.4839 & 5.2756 \\
\hline $10-2008$ & 2.8472 & 3.6330 & 2.4803 & 4.6092 & $9-2012$ & 3.1780 & 4.1138 & 3.4008 & 5.1571 \\
\hline $11-2008$ & 2.9196 & 3.7572 & 2.4273 & 4.4943 & $10-2012$ & 3.1806 & 4.1350 & 3.4249 & 5.1265 \\
\hline $12-2008$ & 2.9618 & 4.1724 & 2.8014 & 4.2913 & $11-2012$ & 3.1585 & 4.1064 & 3.4088 & 5.0621 \\
\hline $1-2009$ & 3.4561 & 4.4392 & 2.9907 & 4.9311 & $12-2012$ & 3.0996 & 4.0882 & 3.3868 & 5.0119 \\
\hline $2-2009$ & 3.6758 & 4.6578 & 3.1355 & 5.2182 & $1-2013$ & 3.0874 & 4.1870 & 3.3890 & 4.8885 \\
\hline $3-2009$ & 3.5416 & 4.7013 & 3.1001 & 5.0546 & $2-2013$ & 3.1679 & 4.1570 & 3.4072 & 4.8058 \\
\hline $4-2009$ & 3.2859 & 4.3838 & 2.9044 & 4.8926 & $3-2013$ & 3.2590 & 4.1774 & 3.4323 & 4.9528 \\
\hline $5-2009$ & 3.1812 & 4.4588 & 2.9438 & 5.1148 & $4-2013$ & 3.1721 & 4.1429 & 3.3821 & 4.9148 \\
\hline $6-2009$ & 3.1733 & 4.4696 & 2.9314 & 5.2745 & $5-2013$ & 3.2953 & 4.2902 & 3.4569 & 5.0181 \\
\hline $7-2009$ & 2.9525 & 4.1605 & 2.7128 & 4.8832 & 6-2013 & 3.3175 & 4.3292 & 3.5078 & 5.0604 \\
\hline $8-2009$ & 2.8675 & 4.0998 & 2.7037 & 4.6546 & $7-2013$ & 3.1929 & 4.2427 & 3.4465 & 4.8577 \\
\hline $9-2009$ & 2.8852 & 4.2226 & 2.7976 & 4.6443 & $8-2013$ & 3.2209 & 4.2654 & 3.4632 & 4.9899 \\
\hline $10-2009$ & 2.8595 & 4.2430 & 2.8104 & 4.7228 & $9-2013$ & 3.1227 & 4.2163 & 3.4500 & 5.0452 \\
\hline $11-2009$ & 2.7538 & 4.1431 & 2.7476 & 4.5544 & $10-2013$ & 3.0507 & 4.1766 & 3.3875 & 4.8872 \\
\hline $12-2009$ & 2.8503 & 4.1082 & 2.7661 & 4.5986 & $11-2013$ & 3.0846 & 4.1998 & 3.4084 & 5.0348 \\
\hline $1-2010$ & 2.9083 & 4.0616 & 2.7677 & 4.6971 & $12-2013$ & 3.0120 & 4.1472 & 3.3816 & 4.9828 \\
\hline $2-2010$ & 2.9251 & 3.9768 & 2.7169 & 4.4615 & $1-2014$ & 3.1288 & 4.2368 & 3.4644 & 5.1458 \\
\hline $3-2010$ & 2.8720 & 3.8622 & 2.7000 & 4.3491 & 2-2014 & 3.0254 & 4.1602 & 3.4211 & 5.0697 \\
\hline $4-2010$ & 2.9305 & 3.9020 & 2.7200 & 4.5042 & 3-2014 & 3.0344 & 4.1713 & 3.4192 & 5.0485 \\
\hline $5-2010$ & 3.3132 & 4.0770 & 2.8661 & 4.8047 & $4-2014$ & 3.0440 & 4.1994 & 3.4433 & 5.1181 \\
\hline $6-2010$ & 3.3946 & 4.1458 & 3.1345 & 5.0947 & $5-2014$ & 3.0435 & 4.1420 & 3.3924 & 5.0928 \\
\hline $7-2010$ & 3.0731 & 4.0080 & 2.9547 & 4.7997 & 6-2014 & 3.0473 & 4.1609 & 3.4246 & 5.1885 \\
\hline $8-2010$ & 3.1583 & 4.0038 & 3.1012 & 4.8714 & $7-2014$ & 3.1094 & 4.1640 & 3.4225 & 5.2506 \\
\hline $9-2010$ & 2.9250 & 3.9870 & 2.9955 & 4.6458 & 8-2014 & 3.1965 & 4.2129 & 3.4930 & 5.3056 \\
\hline $10-2010$ & 2.8873 & 3.9944 & 2.9236 & 4.5950 & $9-2014$ & 3.2973 & 4.1755 & 3.4600 & 5.3549 \\
\hline $11-2010$ & 3.1308 & 4.0734 & 3.1359 & 4.8638 & $10-2014$ & 3.3459 & 4.2043 & 3.4860 & 5.3503 \\
\hline $12-2010$ & 2.9641 & 3.9603 & 3.1639 & 4.5938 & $11-2014$ & 3.3605 & 4.1814 & 3.4788 & 5.2805 \\
\hline $1-2011$ & 2.8845 & 3.9345 & 3.0590 & 4.5769 & $12-2014$ & 3.5072 & 4.2623 & 3.5447 & 5.4648 \\
\hline $2-2011$ & 2.8765 & 3.9763 & 3.1043 & 4.6583 & $1-2015$ & 3.7204 & 4.2081 & 4.0179 & 5.6089 \\
\hline $3-2011$ & 2.8229 & 4.0119 & 3.0825 & 4.5530 & $2-2015$ & 3.6980 & 4.1495 & 3.8919 & 5.6924 \\
\hline 4-2011 & 2.6501 & 3.9376 & 3.0533 & 4.4215 & $3-2015$ & 3.8125 & 4.0890 & 3.9110 & 5.6295 \\
\hline $5-2011$ & 2.7468 & 3.9569 & 3.2254 & 4.5312 & $4-2015$ & 3.5987 & 4.0337 & 3.8438 & 5.5622 \\
\hline $6-2011$ & 2.7517 & 3.9866 & 3.3004 & 4.4102 & $5-2015$ & 3.7671 & 4.1301 & 3.9910 & 5.7590 \\
\hline $7-2011$ & 2.8109 & 4.0125 & 3.5080 & 4.5768 & 6-2015 & 3.7645 & 4.1944 & 4.0412 & 5.9180 \\
\hline 8-2011 & 2.8695 & 4.1445 & 3.5373 & 4.6728 & $7-2015$ & 3.7929 & 4.1488 & 3.9355 & 5.9045 \\
\hline $9-2011$ & 3.2574 & 4.4112 & 3.6165 & 5.0832 & $8-2015$ & 3.7780 & 4.2344 & 3.9238 & 5.8309 \\
\hline $10-2011$ & 3.1024 & 4.3433 & 3.5612 & 4.9683 & $9-2015$ & 3.7754 & 4.2386 & 3.8785 & 5.7305 \\
\hline
\end{tabular}

Source: Table of month end average exchange rates. Retrieved from http://www.nbp.pl/home.aspx?c=/ascx/archa.ascx 
Table 2. Growth rate of housing loans year to year

\begin{tabular}{|c|c|c|c|c|c|c|c|}
\hline & \begin{tabular}{|c|}
$\begin{array}{c}\text { Zloty housing } \\
\text { loans }\end{array}$ \\
\end{tabular} & $\begin{array}{l}\text { Foreign currency } \\
\text { housing loans }\end{array}$ & Total & & \begin{tabular}{|c}
$\begin{array}{c}\text { Zloty housing } \\
\text { loans }\end{array}$ \\
\end{tabular} & $\begin{array}{l}\text { Foreign currency } \\
\text { housing loans }\end{array}$ & Total \\
\hline $12-2007$ & $86.3 \%$ & $43.0 \%$ & $58.9 \%$ & $11-2011$ & $24.2 \%$ & $2.6 \%$ & $10.3 \%$ \\
\hline $1-2008$ & $80.6 \%$ & $43.3 \%$ & $57.1 \%$ & $12-2011$ & $22.8 \%$ & $2.2 \%$ & $9.6 \%$ \\
\hline $2-2008$ & $75.5 \%$ & $44.5 \%$ & $56.1 \%$ & $1-2012$ & $22.1 \%$ & $2.2 \%$ & $9.4 \%$ \\
\hline $3-2008$ & $71.1 \%$ & $46.0 \%$ & $55.6 \%$ & 2-2012 & $21.6 \%$ & $2.1 \%$ & $9.1 \%$ \\
\hline $4-2008$ & $62.7 \%$ & $48.8 \%$ & $54.2 \%$ & 3-2012 & $20.7 \%$ & $1.6 \%$ & $8.6 \%$ \\
\hline $5-2008$ & $53.7 \%$ & $50.9 \%$ & $51.9 \%$ & $4-2012$ & $19.9 \%$ & $1.2 \%$ & $8.0 \%$ \\
\hline $6-2008$ & $44.4 \%$ & $54.1 \%$ & $49.8 \%$ & 5-2012 & $19.3 \%$ & $0.7 \%$ & $7.5 \%$ \\
\hline $7-2008$ & $35.6 \%$ & $57.5 \%$ & $47.8 \%$ & 6-2012 & $19.1 \%$ & $0.0 \%$ & $7.0 \%$ \\
\hline $8-2008$ & $28.1 \%$ & $60.0 \%$ & $45.7 \%$ & $7-2012$ & $18.8 \%$ & $-0.6 \%$ & $6.6 \%$ \\
\hline $9-2008$ & $22.6 \%$ & $63.2 \%$ & $44.9 \%$ & $8-2012$ & $18.9 \%$ & $-0.8 \%$ & $6.6 \%$ \\
\hline $10-2008$ & $18.0 \%$ & $65.8 \%$ & $44.2 \%$ & $9-2012$ & $18.2 \%$ & $-1.5 \%$ & $6.0 \%$ \\
\hline $11-2008$ & $13.7 \%$ & $63.5 \%$ & $40.9 \%$ & $10-2012$ & $18.2 \%$ & $-2.1 \%$ & $5.7 \%$ \\
\hline $12-2008$ & $12.3 \%$ & $61.3 \%$ & $39.1 \%$ & $11-2012$ & $18.4 \%$ & $-2.7 \%$ & $5.4 \%$ \\
\hline $1-2009$ & $11.3 \%$ & $57.5 \%$ & $36.6 \%$ & $12-2012$ & $18.2 \%$ & $-3.3 \%$ & $5.1 \%$ \\
\hline $2-2009$ & $10.8 \%$ & $53.5 \%$ & $34.4 \%$ & $1-2013$ & $18.4 \%$ & $-3.8 \%$ & $5.0 \%$ \\
\hline $3-2009$ & $8.7 \%$ & $48.3 \%$ & $30.5 \%$ & $2-2013$ & $18.4 \%$ & $-4.2 \%$ & $4.8 \%$ \\
\hline $4-2009$ & $9.4 \%$ & $42.4 \%$ & $27.5 \%$ & $3-2013$ & $18.0 \%$ & $-4.4 \%$ & $4.6 \%$ \\
\hline $5-2009$ & $10.7 \%$ & $36.5 \%$ & $24.9 \%$ & 4-2013 & $17.8 \%$ & $-4.6 \%$ & $4.5 \%$ \\
\hline $6-2009$ & $12.7 \%$ & $29.9 \%$ & $22.1 \%$ & 5-2013 & $17.6 \%$ & $-4.9 \%$ & $4.3 \%$ \\
\hline $7-2009$ & $15.7 \%$ & $23.2 \%$ & $19.4 \%$ & 6-2013 & $17.1 \%$ & $-5.0 \%$ & $4.2 \%$ \\
\hline $8-2009$ & $18.4 \%$ & $17.9 \%$ & $17.2 \%$ & $7-2013$ & $17.0 \%$ & $-5.1 \%$ & $4.2 \%$ \\
\hline $9-2009$ & $21.9 \%$ & $13.0 \%$ & $15.4 \%$ & $8-2013$ & $16.8 \%$ & $-5.2 \%$ & $4.2 \%$ \\
\hline $10-2009$ & $25.5 \%$ & $8.7 \%$ & $13.7 \%$ & $9-2013$ & $16.9 \%$ & $-5.3 \%$ & $4.2 \%$ \\
\hline $11-2009$ & $27.1 \%$ & $6.9 \%$ & $13.0 \%$ & $10-2013$ & $16.9 \%$ & $-5.4 \%$ & $4.3 \%$ \\
\hline $12-2009$ & $28.1 \%$ & $5.8 \%$ & $12.5 \%$ & $11-2013$ & $16.8 \%$ & $-5.4 \%$ & $4.3 \%$ \\
\hline $1-2010$ & $29.0 \%$ & $5.3 \%$ & $12.5 \%$ & $12-2013$ & $16.9 \%$ & $-5.5 \%$ & $4.4 \%$ \\
\hline $2-2010$ & $29.7 \%$ & $4.9 \%$ & $12.5 \%$ & $1-2014$ & $16.9 \%$ & $-5.5 \%$ & $4.5 \%$ \\
\hline $3-2010$ & $30.4 \%$ & $4.9 \%$ & $12.7 \%$ & 2-2014 & $16.9 \%$ & $-5.6 \%$ & $4.6 \%$ \\
\hline 4-2010 & $30.7 \%$ & $4.9 \%$ & $13.0 \%$ & 3-2014 & $16.8 \%$ & $-5.7 \%$ & $4.6 \%$ \\
\hline $5-2010$ & $30.9 \%$ & $5.2 \%$ & $13.4 \%$ & 4-2014 & $16.8 \%$ & $-5.7 \%$ & $4.6 \%$ \\
\hline $6-2010$ & $31.0 \%$ & $5.4 \%$ & $13.7 \%$ & $5-2014$ & $16.7 \%$ & $-5.6 \%$ & $4.7 \%$ \\
\hline $7-2010$ & $30.6 \%$ & $5.7 \%$ & $13.8 \%$ & 6-2014 & $16.6 \%$ & $-5.7 \%$ & $4.7 \%$ \\
\hline $8-2010$ & $30.5 \%$ & $5.8 \%$ & $13.9 \%$ & $7-2014$ & $16.3 \%$ & $-5.8 \%$ & $4.6 \%$ \\
\hline $9-2010$ & $29.9 \%$ & $5.8 \%$ & $13.8 \%$ & $8-2014$ & $15.9 \%$ & $-5.8 \%$ & $4.5 \%$ \\
\hline $10-2010$ & $29.4 \%$ & $5.8 \%$ & $13.7 \%$ & $9-2014$ & $15.5 \%$ & $-5.9 \%$ & $4.4 \%$ \\
\hline $11-2010$ & $29.3 \%$ & $5.7 \%$ & $13.7 \%$ & $10-2014$ & $14.8 \%$ & $-5.9 \%$ & $4.2 \%$ \\
\hline $12-2010$ & $29.5 \%$ & $5.7 \%$ & $13.8 \%$ & $11-2014$ & $14.4 \%$ & $-6.0 \%$ & $4.0 \%$ \\
\hline $1-2011$ & $29.4 \%$ & $5.4 \%$ & $13.6 \%$ & $12-2014$ & $13.9 \%$ & $-6.2 \%$ & $3.8 \%$ \\
\hline $2-2011$ & $29.1 \%$ & $5.2 \%$ & $13.4 \%$ & $1-2015$ & $13.5 \%$ & $-6.0 \%$ & $3.7 \%$ \\
\hline $3-2011$ & $29.1 \%$ & $5.0 \%$ & $13.3 \%$ & 2-2015 & $13.2 \%$ & $-6.1 \%$ & $3.6 \%$ \\
\hline $4-2011$ & $29.1 \%$ & $4.8 \%$ & $13.2 \%$ & 3-2015 & $13.2 \%$ & $-6.1 \%$ & $3.6 \%$ \\
\hline $5-2011$ & $29.0 \%$ & $4.4 \%$ & $13.0 \%$ & $4-2015$ & $12.8 \%$ & $-6.2 \%$ & $3.4 \%$ \\
\hline $6-2011$ & $28.4 \%$ & $4.1 \%$ & $12.6 \%$ & 5-2015 & $12.6 \%$ & $-6.4 \%$ & $3.2 \%$ \\
\hline $7-2011$ & $27.7 \%$ & $3.8 \%$ & $12.3 \%$ & $6-2015$ & $12.4 \%$ & $-6.4 \%$ & $3.1 \%$ \\
\hline $8-2011$ & $26.6 \%$ & $3.1 \%$ & $11.5 \%$ & $7-2015$ & $12.3 \%$ & $-6.5 \%$ & $3.1 \%$ \\
\hline $9-2011$ & $26.4 \%$ & $2.8 \%$ & $11.2 \%$ & $8-2015$ & $12.2 \%$ & $-6.6 \%$ & $3.0 \%$ \\
\hline $10-2011$ & $25.4 \%$ & $2.6 \%$ & $10.8 \%$ & $9-2015$ & $11.8 \%$ & $-6.6 \%$ & $2.8 \%$ \\
\hline
\end{tabular}

Source: Retrieved from http://www.nbp.pl/systemfinansowy/rsf022016.pdf. 
Table 3. Increase in the value of Swiss franc denominated housing loan instalment to instalment at loan origination against values of Swiss franc denominated loans and wage growth in the enterprise sector

\begin{tabular}{|c|c|c|c|c|c|c|c|c|c|}
\hline & 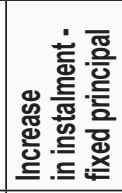 & 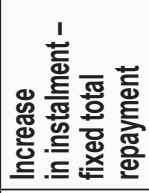 & 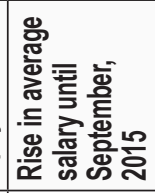 & 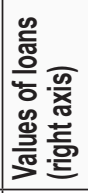 & & 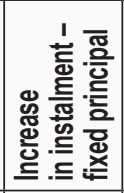 & 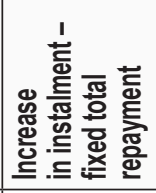 & 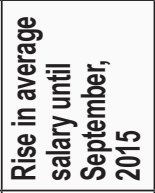 & 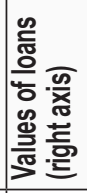 \\
\hline $1-2005$ & 0.03 & 0.32 & 0.70 & 0.51 & $1-2008$ & -0.02 & 0.24 & 0.37 & 3.15 \\
\hline $2-2005$ & 0.06 & 0.36 & 0.68 & 0.46 & $2-2008$ & -0.03 & 0.23 & 0.34 & 3.58 \\
\hline $3-2005$ & 0.05 & 0.34 & 0.64 & 0.64 & 3-2008 & -0.05 & 0.20 & 0.29 & 4.38 \\
\hline $4-2005$ & 0.01 & 0.30 & 0.64 & 0.72 & $4-2008$ & -0.01 & 0.25 & 0.29 & 5.58 \\
\hline $5-2005$ & 0.01 & 0.28 & 0.67 & 0.83 & $5-2008$ & 0.03 & 0.29 & 0.32 & 5.37 \\
\hline $6-2005$ & 0.03 & 0.32 & 0.62 & 1.08 & $6-2008$ & 0.02 & 0.29 & 0.26 & 6.35 \\
\hline $7-2005$ & 0.04 & 0.32 & 0.62 & 1.11 & 7-2008 & 0.07 & 0.34 & 0.26 & 6.91 \\
\hline $8-2005$ & 0.05 & 0.33 & 0.64 & 1.06 & $8-2008$ & 0.07 & 0.34 & 0.28 & 5.69 \\
\hline $9-2005$ & 0.08 & 0.37 & 0.63 & 1.10 & 9-2008 & 0.03 & 0.28 & 0.28 & 5.92 \\
\hline $10-2005$ & 0.07 & 0.36 & 0.60 & 1.20 & $10-2008$ & -0.10 & 0.12 & 0.25 & 4.83 \\
\hline $11-2005$ & 0.04 & 0.32 & 0.52 & 1.23 & 11-2008 & 0.00 & 0.22 & 0.22 & 1.82 \\
\hline $12-2005$ & 0.06 & 0.35 & 0.46 & 1.42 & $12-2008$ & 0.06 & 0.27 & 0.19 & 1.32 \\
\hline $1-2006$ & 0.07 & 0.36 & 0.64 & 1.32 & $1-2009$ & 0.03 & 0.22 & 0.26 & 0.73 \\
\hline $2-2006$ & 0.08 & 0.37 & 0.61 & 1.23 & 2-2009 & -0.06 & 0.11 & 0.27 & 0.63 \\
\hline 3-2006 & 0.04 & 0.33 & 0.55 & 1.96 & 3-2009 & -0.03 & 0.13 & 0.22 & 0.71 \\
\hline 4-2006 & 0.03 & 0.31 & 0.58 & 1.83 & 4-2009 & 0.03 & 0.20 & 0.23 & 0.51 \\
\hline $5-2006$ & 0.01 & 0.29 & 0.59 & 2.08 & $5-2009$ & 0.03 & 0.19 & 0.27 & 0.49 \\
\hline $6-2006$ & -0.03 & 0.24 & 0.55 & 2.32 & 6-2009 & 0.00 & 0.18 & 0.23 & 0.43 \\
\hline $7-2006$ & -0.03 & 0.24 & 0.53 & 2.29 & $7-2009$ & 0.06 & 0.24 & 0.21 & 0.41 \\
\hline $8-2006$ & -0.01 & 0.27 & 0.55 & 2.14 & $8-2009$ & 0.11 & 0.29 & 0.24 & 0.45 \\
\hline $9-2006$ & -0.04 & 0.23 & 0.55 & 2.04 & $9-2009$ & 0.10 & 0.29 & 0.24 & 0.99 \\
\hline $10-2006$ & -0.03 & 0.24 & 0.53 & 2.25 & $10-2009$ & 0.10 & 0.27 & 0.23 & 0.64 \\
\hline $11-2006$ & -0.02 & 0.26 & 0.47 & 2.25 & 11-2009 & 0.11 & 0.28 & 0.19 & 0.38 \\
\hline $12-2006$ & -0.02 & 0.25 & 0.34 & 2.77 & $12-2009$ & 0.11 & 0.28 & 0.11 & 0.53 \\
\hline $1-2007$ & -0.05 & 0.22 & 0.52 & 1.87 & $1-2010$ & 0.12 & 0.28 & 0.26 & 0.46 \\
\hline 2-2007 & -0.05 & 0.21 & 0.51 & 1.86 & $2-2010$ & 0.13 & 0.29 & 0.23 & 0.18 \\
\hline 3-2007 & -0.06 & 0.20 & 0.42 & 2.34 & 3-2010 & 0.15 & 0.31 & 0.16 & 0.25 \\
\hline 4-2007 & -0.04 & 0.23 & 0.46 & 2.43 & 4-2010 & 0.15 & 0.31 & 0.19 & 0.20 \\
\hline $5-2007$ & -0.03 & 0.24 & 0.46 & 2.67 & $5-2010$ & 0.10 & 0.25 & 0.21 & 0.21 \\
\hline $6-2007$ & -0.05 & 0.22 & 0.41 & 3.08 & 6-2010 & 0.06 & 0.20 & 0.19 & 0.23 \\
\hline $7-2007$ & -0.06 & 0.21 & 0.40 & 3.08 & $7-2010$ & 0.04 & 0.18 & 0.18 & 0.23 \\
\hline $8-2007$ & -0.09 & 0.17 & 0.41 & 2.86 & $8-2010$ & 0.06 & 0.20 & 0.19 & 0.25 \\
\hline $9-2007$ & -0.08 & 0.18 & 0.42 & 2.52 & 9-2010 & 0.04 & 0.18 & 0.19 & 0.03 \\
\hline $10-2007$ & -0.04 & 0.23 & 0.38 & 2.98 & $10-2010$ & 0.07 & 0.21 & 0.18 & 0.03 \\
\hline $11-2007$ & -0.03 & 0.23 & 0.31 & 2.76 & $11-2010$ & 0.07 & 0.21 & 0.15 & 0.04 \\
\hline $12-2007$ & -0.01 & 0.26 & 0.25 & 2.84 & $12-2010$ & 0.02 & 0.14 & 0.05 & 0.03 \\
\hline
\end{tabular}

Source: Retrieved from http://www.nbp.pl/systemfinansowy/rsf022016.pdf. 
Increased costs of debt servicing for households resulted in changes in the share of impaired credits in banks' portfolios in the analysed period 2010-2015. For housing loans which include CHF credits, it (the share) rose by less than 2 percentage points. However, in fact it means a periodic doubling of this value. The data concerning households' impaired credits classified by main categories are collected in table 4.

Table 4. Impaired loan ratios of main categories of loans for households

\begin{tabular}{|c|c|c|c|c|c|c|c|c|c|c|c|}
\hline & $\begin{array}{c}\text { Credit } \\
\text { card } \\
\text { lending }\end{array}$ & \begin{tabular}{|c|} 
Other \\
consumer \\
loans
\end{tabular} & $\begin{array}{l}\text { Housing } \\
\text { loans }\end{array}$ & Other & Total & & $\begin{array}{c}\text { Credit } \\
\text { card } \\
\text { lending }\end{array}$ & $\begin{array}{l}\text { Other } \\
\text { consumer } \\
\text { loans }\end{array}$ & $\begin{array}{c}\text { Housing } \\
\text { loans }\end{array}$ & Other & Tota \\
\hline $4-2010$ & $5.65 \%$ & $15.34 \%$ & $157 \%$ & $96 \%$ & $6.76 \%$ & -2013 & $16.83 \%$ & $17.46 \%$ & & $.56 \%$ & 7.46 \\
\hline $5-2010$ & $.13 \%$ & $60 \%$ & $\%$ & $97 \%$ & $6.77 \%$ & 2013 & $.85 \%$ & $\%$ & & $.62 \%$ & $7.46 \%$ \\
\hline 6-2010 & $.30 \%$ & $5.79 \%$ & $9 \%$ & $7.26 \%$ & $6.69 \%$ & 3-2013 & $0.90 \%$ & $7.34 \%$ & & $10.72 \%$ & $7.47 \%$ \\
\hline $7-2010$ & $.73 \%$ & $6.22 \%$ & $\%$ & $7.20 \%$ & $6.92 \%$ & \begin{tabular}{|l|}
$4-2013$ \\
\end{tabular} & $.70 \%$ & $\%$ & & $10.85 \%$ & $7.53 \%$ \\
\hline $8-2010$ & $17.26 \%$ & $6.56 \%$ & & $7.47 \%$ & $7.00 \%$ & -2013 & $16.43 \%$ & $17.25 \%$ & & $10.91 \%$ & $7.49 \%$ \\
\hline 9-2010 & $17.48 \%$ & $16.94 \%$ & $\%$ & $7.63 \%$ & $7.19 \%$ & 6-2013 & $15.52 \%$ & $16.10 \%$ & & $10.90 \%$ & $7.21 \%$ \\
\hline $0-2010$ & $97 \%$ & $7.06 \%$ & & $7.97 \%$ & $7.30 \%$ & & $15.23 \%$ & $16.05 \%$ & & $10.89 \%$ & $7.22 \%$ \\
\hline $11-2010$ & $18.22 \%$ & $17.24 \%$ & $2 \%$ & $7.90 \%$ & $7.21 \%$ & 8-2013 & $15.05 \%$ & $15.96 \%$ & $\% \%$ & $10.91 \%$ & $7.19 \%$ \\
\hline $12-2010$ & $18.09 \%$ & $7.18 \%$ & & $8.14 \%$ & $7.18 \%$ & 13 & $14.60 \%$ & $15.59 \%$ & & $10.63 \%$ & $7.09 \%$ \\
\hline 1-2011 & $18.79 \%$ & $18.28 \%$ & $1.92 \%$ & $8.11 \%$ & $7.53 \%$ & $10-2013$ & $14.42 \%$ & $15.16 \%$ & $6 \%$ & $10.98 \%$ & $7.09 \%$ \\
\hline $2-2011$ & $9.09 \%$ & $8.20 \%$ & & $8.16 \%$ & $7.49 \%$ & 11- & $14.49 \%$ & $14.93 \%$ & & $11.03 \%$ & $7.15 \%$ \\
\hline 3-2011 & $19.70 \%$ & $17.99 \%$ & $2.00 \%$ & $8.19 \%$ & $7.44 \%$ & $12-2013$ & $13.98 \%$ & $14.68 \%$ & $4 \%$ & $10.98 \%$ & $7.07 \%$ \\
\hline 4-2011 & $3.77 \%$ & $.69 \%$ & & $8.17 \%$ & $7.31 \%$ & & $14.14 \%$ & $14.73 \%$ & & $10.99 \%$ & $7.06 \%$ \\
\hline $5-2011$ & $18.80 \%$ & $17.79 \%$ & $2.05 \%$ & $8.19 \%$ & $7.26 \%$ & 2-2014 & $14.09 \%$ & $14.76 \%$ & $6 \%$ & $10.90 \%$ & $7.07 \%$ \\
\hline 6-2011 & $37 \%$ & $.77 \%$ & & $.13 \%$ & $7.17 \%$ & 14 & $14.02 \%$ & $14.39 \%$ & $\%$ & $10.90 \%$ & $6.97 \%$ \\
\hline $7-2011$ & $19.02 \%$ & $17.99 \%$ & $0 \%$ & $8.15 \%$ & $7.14 \%$ & 4-2014 & $13.74 \%$ & $14.39 \%$ & $9 \%$ & $10.95 \%$ & $7.02 \%$ \\
\hline $8-2$ & $19.10 \%$ & $.92 \%$ & & $8.56 \%$ & $7.22 \%$ & & $13.57 \%$ & $14.42 \%$ & & $11.01 \%$ & $7.06 \%$ \\
\hline $9-2011$ & $19.23 \%$ & $18.21 \%$ & $2 \%$ & $9.13 \%$ & $7.34 \%$ & 14 & $13.16 \%$ & $14.20 \%$ & $6 \%$ & $11.01 \%$ & $6.98 \%$ \\
\hline 10-2011 & & $14 \%$ & & $9.24 \%$ & $7.36 \%$ & & $13.01 \%$ & $14.01 \%$ & & $11.05 \%$ & $6.96 \%$ \\
\hline $11-2011$ & $14 \%$ & $18.18 \%$ & $9 \%$ & $9.22 \%$ & $7.30 \%$ & $8-2$ & $12.97 \%$ & $13.99 \%$ & $\%$ & $11.12 \%$ & $6.96 \%$ \\
\hline 12-2011 & $18.76 \%$ & $.85 \%$ & & $9.27 \%$ & $7.25 \%$ & 14 & $12.73 \%$ & $13.89 \%$ & $9 \%$ & $10.94 \%$ & $6.94 \%$ \\
\hline $1-2012$ & $19.14 \%$ & $.97 \%$ & & $9.36 \%$ & $7.37 \%$ & $10-2$ & $12.19 \%$ & $13.21 \%$ & $\%$ & $10.69 \%$ & $6.77 \%$ \\
\hline 2-2012 & $.09 \%$ & $3.23 \%$ & $\%$ & $9.37 \%$ & $7.45 \%$ & $11-2014$ & $12.03 \%$ & $13.21 \%$ & $\%$ & $10.67 \%$ & $6.75 \%$ \\
\hline 3-2012 & $19.00 \%$ & $8.25 \%$ & $1 \%$ & $9.38 \%$ & $7.46 \%$ & $12-2014$ & $11.74 \%$ & $12.82 \%$ & $0 \%$ & $10.53 \%$ & $6.54 \%$ \\
\hline 4-2012 & $18.64 \%$ & $18.25 \%$ & $\%$ & $9.49 \%$ & $7.46 \%$ & \begin{tabular}{|l|}
$1-2015$ \\
\end{tabular} & $11.87 \%$ & $12.89 \%$ & $\%$ & $10.66 \%$ & $6.48 \%$ \\
\hline 5-2012 & $18.47 \%$ & $7.86 \%$ & $1 \%$ & $9.52 \%$ & $7.32 \%$ & 2-2015 & $11.69 \%$ & $12.76 \%$ & $12 \%$ & $10.64 \%$ & $6.49 \%$ \\
\hline 6-2012 & $18.27 \%$ & $17.75 \%$ & $2.59 \%$ & $9.55 \%$ & $7.31 \%$ & 3-2015 & $12.20 \%$ & $13.04 \%$ & $6 \%$ & $10.88 \%$ & $6.75 \%$ \\
\hline $7-2012$ & $18.21 \%$ & $17.87 \%$ & $2.65 \%$ & $9.67 \%$ & $7.43 \%$ & 4-2015 & $11.88 \%$ & $12.76 \%$ & $26 \%$ & $10.68 \%$ & $6.62 \%$ \\
\hline 8-2012 & $18.07 \%$ & $17.98 \%$ & $2.68 \%$ & $9.87 \%$ & $7.46 \%$ & \begin{tabular}{|l|}
$5-2015$ \\
\end{tabular} & $11.81 \%$ & $12.73 \%$ & $3 \%$ & $10.72 \%$ & $6.61 \%$ \\
\hline 9-2012 & $17.81 \%$ & $17.93 \%$ & $2.67 \%$ & $10.15 \%$ & $7.51 \%$ & 6-2015 & $10.73 \%$ & $12.26 \%$ & $88 \%$ & $10.79 \%$ & $6.56 \%$ \\
\hline $10-2012$ & $17.74 \%$ & $17.82 \%$ & $2.72 \%$ & $10.25 \%$ & $7.50 \%$ & \begin{tabular}{|l|}
$7-2015$ \\
\end{tabular} & $10.42 \%$ & $12.16 \%$ & $37 \%$ & $10.71 \%$ & $6.54 \%$ \\
\hline 11-2012 & $17.73 \%$ & $17.69 \%$ & $2.75 \%$ & $10.28 \%$ & $7.48 \%$ & $8-2015$ & $10.31 \%$ & $12.30 \%$ & $38 \%$ & $10.69 \%$ & $6.58 \%$ \\
\hline 2012 & $16.80 \%$ & $17.27 \%$ & $2.82 \%$ & $10.47 \%$ & $7.42 \%$ & 9-2015 & $9.85 \%$ & $12.18 \%$ & $\%$ & $10.70 \%$ & $6.47 \%$ \\
\hline
\end{tabular}

Source: Retrieved from http://www.nbp.pl/systemfinansowy/rsf022016.pdf 
Although growth of impaired loans was caused only to a little extent by changes in the CHF exchange rate, projects of helping bank customers who took the loans in this currency are widely discussed. Different assistance variants based on converting the loans into Polish zloty according to the historic exchange rate are discussed. The National Bank of Poland presented two most probable scenarios of the impact of these activities on the situation of banks measured by a change in the Return on Assets (ROA) indicator. Considering the fact that the share of mortgage loans, including those given in CHF, in banks' assets is varied, a percentage change in total bank assets for which the ROA indicator is within the accepted range was examined. Detailed data of the simulation are given in table 5 .

Table 5. Results of the simulation of the impact of the introduction of restructuring of foreign currency loans on commercial banks' ROA

\begin{tabular}{|c|c|c|c|}
\hline \multicolumn{4}{|c|}{ Share in domestic commercial banks' assets } \\
\hline ROA & As of September 2015 & Scenario I* all borrowers & $\begin{array}{c}\text { Scenario I** borrowers who took loans } \\
\text { in the years 2007-2008 }\end{array}$ \\
\hline$<-3 \%$ & $0.0 \%$ & $35.7 \%$ & $35.0 \%$ \\
\hline$<-3 \% ;-2 \%)$ & $0.0 \%$ & $20.3 \%$ & $21.0 \%$ \\
\hline$<-2 \% ;-1 \%)$ & $0.0 \%$ & $11.9 \%$ & $11.9 \%$ \\
\hline$<-1 \% ; 0 \%)$ & $8.1 \%$ & $3.0 \%$ & $0.2 \%$ \\
\hline$<0 \% ;+1 \%)$ & $52.1 \%$ & $24.8 \%$ & $27.6 \%$ \\
\hline$>=+1 \%$ & $39.8 \%$ & $4.2 \%$ & $4.2 \%$ \\
\hline
\end{tabular}

* Reimbursement of spreads and loan restructuring according to the historic exchange rate defined in the Act will include all borrowers who took loans in CHF regardless of the time when the credit agreement was concluded. ** Reimbursement of spreads will cover all borrowers who took loans in CHF regardless of the time when the loan agreement was concluded, however, restructuring loans according to the historic exchange rate defined in the Act will cover all borrowers who took loans in CHF in the years 2007-2008.

Source: Retrieved from http://www.nbp.pl/systemfinansowy/rsf022016.pdf

Conclusions from the simulations carried out by the National Bank of Poland (NBP) are rather pessimistic for the banking sector. According to the analysts' calculations the banking sector as a whole will lose ca. 44 billion zloty in the case of implementing the second variant of assistance for borrowers. In the case the first variant is implemented, this amount can be higher by ca. 20 billion (Report on the financial system stability, February 2016, p. 31).

\section{Conclusions}

The data presented in this paper let us formulate a conclusion that banks' credit policy including offering housing loans in CHF was a typical activity from the point of view of risk management, which in this case is of two-way nature. Banks did not have 
a possibility to affect the zloty exchange rate in relation to other currencies and similarly to other market participants took risks. If the CHF exchange rate depreciated in relation to the zloty, customers who had liabilities in the currency would gain additional profits on account of differences in exchange rates. The situation for banks would be unfavourable. The share of CHF loans in banks' credit portfolios does not threaten stability of the banking system.

Considering the degree of the financial market development in Poland, it is hard to believe that banks used their monopolistic position as they do not enjoy one. Thus, they do not have a possibility of imposing their policy on clients. This is also indicated by differences in the interest rates on the loans in zloty and in foreign currencies.

Restructuring of mortgage loans in CHF according to the historic exchange rate may undermine stability of the banking system and become a dangerous precedent in market economy.

\section{References}

Capiga, M., Gradoń, W., Szustak, G. (2013). Systemy wczesnego ostrzegania w ocenie działalności instytucji finansowych. Warszawa, CeDeWu.

Commons, J. R. (1990). Institutional Economics. Its Place in Political Economy. (Vol. I). New Brunswick-London, Transaction Publishers.

Danielsson, J., Zigrand, J. P., Shin, H. S. (2009). Risk Appetite and Endogenous Risk. Mimeo, London School of Economics.

Fedorowicz, Z. (1996). Ryzyko bankowe. Warszawa, PWSBiA.

Forlicz, S. (2001), Niedoskonała wiedza podmiotów rynkowych. Warszawa. PWN.

Gątarek, D., Maksymiuk. R., Krysiak, M., Witkowski, Ł. (2001). Nowoczesne metody zarządzania ryzykiem finansowym. Warszawa, WIG PRESS.

Jajuga, K. (1996). Inwestycyje. Instrumenty finansowe. Ryzyko finansowe. Inżynieria finansowa. Warszawa, Wydawnictwo Naukowe PWN.

Janasz, K. (2013). Dylematy ryzyka wzarządzaniu projektami. In K. Janasz \& J. Wiśniewska (eds.). Zarządzanie projektami w organizacji. Warszawa, Difin.

Jaworski, W. L. (1998). Współczesny bank. Warszawa, Poltext.

Kaszubski, R. W. (2006). Funkcjonalne źródła prawa bankowego. Warszawa, Wolters Kluwer SA.

Kaufman, G. G. (1996). Bank Failures, Systemic Risk, and Bank Regulation. Retrieved from http://object.cato.org/sites/cato.org/files/serials/files/cato-journal/1996/5/cj16n1-2. pdf (access 10.05.2018).

Knight, F. H. (1971). Risk, Uncertainty and Profit. Chicago, Chicago University Press.

Konat, W., Sowińska, I. (2001). System monitorowania w BFG sytuacji banków komercyjnych. Bezpieczny Bank, 1(16). 
Krahnen, J. P., Schmidt, R. H. (1994). Development Finance as Institution Building. A New Approach to Poverty - Oriented Banking. Westview Press, Boulder - San Francisco - Oxford.

Książepolski, K. M. (2004). Ekonomiczne zagrożenia bezpieczeństwa państw, Metody i środki przeciwdziałania. Warszawa, Wydawnictwo Elipsa.

Lastra, R. M. (2006). Legal Foundations of International Monetary Stability. Oxford-New York. Majewska, J. (2001). Z doświadczeń restrukturyzacii banków w latach 80. i 90. Retrieved from http://www.nbportal.pl/library/-pub_auto_B_0100/KAT_B4844.PDF (access 10.05.2018).

Merton, R. C. (1995). A Functional Perspective of Financial Intermediation. Financial Management, 24.

Milczewska, D. (1997). Instytucja nadzoru bankowego w Polsce. Warszawa, Instytut Finansów.

Olszewska, G. A. (2013). System bankowy a uwarunkowania wzrostu gospodarczego w krajach Europy Środkowej na przykładzie Polski, Czech, Słowacji i Węgier. Radom, Instytut NaukowoWydawniczy "Spatium”.

Olszewska, G. A. (2012). Komu naprawdę potrzebny jest nowy nadzór finansowy?. In Nowe zjawiska na rynku finansowym. T. Gruszecki \& J. Bednarz (eds.). Lublin, Wydawnictwo KUL.

Olszewska, G. A. (2015). Holding company as an organizational form of enterprise on the financial market. Central European Review of Economics \& Finance, 10(4).

Pietrzak, B., Polański, Z. (1997). System finansowy w Polsce - lata dziewięćdziesiąte. Warszawa, PWN.

Polański, B., Pietrzak, Z., Woźniak, B. (2008). System finansowy w Polsce (Vol. I.). Warszawa, PWN.

Przybylska-Kapuścińska, W. (ed.). (2001). Zarządzanie ryzykiem i płynnością banku komercyjnego. Poznań, Wydawnictwo Akademii Ekonomicznej w Poznaniu.

Rajczyk, M. (1997). Podstawy bankowości komercyjnej. Bielsko-Biała, Fundacja Banku Śląskiego.

Raport o stabilności systemu finansowego, NBP, luty 2016. Retrieved from http://www.nbp.pl/ systemfinansowy/rsf022016.pdf (access 10.05.2018).

Skrzypek, S. (2007). Aspekty instytucjonalne stabilności finansowej a wyzwania europejskie. A speech delivered during a banking forum on 14 March 2007.

Solarz, J. K. (2008). Zarządzanie ryzykiem systemu finansowego. Warszawa, PWN.

Solarz, J. K. (2010). Istota i sposób pomiaru ryzyka systemu finansowego. In B. Filipiak \& M. Dylewski (eds.). Ryzyko w finansach i bankowości. Warszawa, Difin.

Stoner, J. A. F., Wankler, Ch. (1996). Kierowanie. Warszawa, PWE.

Szczepańska, O., Sotomska-Krzysztofik, P., Pawliszyn, M., Pawlikowski, A. (2004). Instytucjonalne uwarunkowania stabilności finansowej na przykładzie wybranych krajów. Materiały i Studia, 173.

The Act „Prawo bankowe” (Banking Law) of 29 Aug. 1997. Journal of Laws 2002, 665(72), 1070(126), 1178(141), 1208(144). 
Williams, C. A., Smith, J. M., Young, P. (2002). Zarządzanie ryzykiem a ubezpieczenia. Warszawa, PWN.

Żyrzyński, J. (2006). System finansowy a gospodarka realna: między służebnością a wyobcowaniem. Ekonomista, 4. 